\title{
CONSTRUCTION MANAGEMENT AND THE SPECIALTY TRADE (PRIME) CONTRACTORS
}

\author{
JoHn B. Tieder, JR. AND ROBERT K. COX*
}

I

\section{INTRODUCTION}

Nonconventional construction techniques such as construction management and design-build/fast track have developed as methods designed to reduce the total time between the date of decision to build and the date of project completion. Any such time savings predominantly benefits the owner. The sooner the project is completed, the sooner it can serve its intended purpose-a factory can produce goods; an office building can produce rental income; a refinery can produce gasoline products; or a power plant can generate electricity. A time savings can also result in reduced construction and financing costs including lower labor rates, material and fuel costs, and interest expense. Because it is the owner who elects to utilize a nonconventional construction technique, it is the owner who must accept not only the benefits but also the costs of such methods.

The purpose of this article is to evaluate the use of construction management and design-build/fast track from the perspective of specialty trade contractors, the group performing the majority of the actual physical construction work. The article will first review the role of specialty contractors under the traditional fixed design and prime contractor-subcontractor system. It will then discuss the expectations of the specialty contractors when nonconventional techniques are to be utilized. Finally, it will evaluate how nonconventional methods have actually worked for specialty trade contractors.

II

\section{The Traditional Role of Specialty Trade Contractors}

A specialty trade contractor is a contractor who performs one specific craft or trade on a construction project. On a typical project, the term would include, among others, the electrical, mechanical (heating and air conditioning), plumbing, roofing, insulation, plaster/drywall, painting, and landscaping contractors. Even on a moderate sized project of fifteen to twenty-five million dollars it is common to have twenty and sometimes as many as forty to fifty specialty contractors, each performing its respective trade.

On a conventional construction project, the owner normally provides a prime

Copyright $(\mathcal{1} 1983$ by Law and Contemporary Problems

* Attorneys, Watt, Tieder, Killian, Toole \& Hoffar, Washington, D.C. 
contractor with a fixed set of plans and specifications for the entire project. The prime contractor agrees to provide the owner with a completed structure in accordance with those plans within a definite period of time, usually for a fixed price. ${ }^{1}$ Thereafter, the prime contractor typically enters into subcontracts with various specialty trade contractors, each of whom agrees to perform a designated trade portion of the prime contract work. As a subcontractor on a conventional project, the specialty trade contractor is responsible to the prime contractor; the specialty contractor has no legal relationship with the owner.

From the specialty contractor's point of view, there are several major drawbacks to the conventional contracting system of construction. The first problem arises at the contract formation stage and is often the cause of subsequent disputes and litigation between prime contractors and subcontractors. At the time of contracting, the specialty contractor typically agrees to perform all work associated with its trade. Frequently, the owner's designer has divided the project plans and specifications by trade. ${ }^{2}$ Nevertheless, the specialty contractor must review and interpret all the project design documents to assure that all its trade work is accounted for. Even then, it is not uncommon for a specialty contractor to fail to account for trade work described in some segment of the project design documents other than in the portion designated to its trade. ${ }^{3}$ When such omissions become known, the prime contractor, who has agreed to present the owner with a complete project, is often pitted against the specialty contractor, who may refuse to perform the omitted work without additional compensation. Eventually, one or the other will perform the work, but often without compensation.

A second drawback also arises at the contract formation stage. The typical subcontract agreement requires the subcontractor to perform its work in accordance with all the terms and conditions of the prime contract with the owner. Because the subcontractor lacks privity of contract with the owner, however, it has no direct access to the owner. Therefore, any questions the subcontractor has about the prime contract must go first to the prime contractor. The owner then responds to the prime contractor, who gives the answer to the subcontractor. Not only does this cause delay, but as with any message, the more parties through

1. Federal and state governments have designated formal advertising and the award of firm fixedprice contracts to be the preferred method of contracting. See, e.g., 10 U.S.C. $\S \S 2304$ (a), 2305 (1976); 32 C.F.R. §IA-2-102.1 (1981) (defense contracts); 41 U.S.C. $\$ 5$ (1976) and 41 C.F.R. $\S 1-2.102$ (1981) (civilian agency contracts)

2. The typical contract specifications, though presented as one package, are generally divided into sections. For example, the contract specifications may be divided as follows:

I. General Requirements

II. Site Work

III. Concrete

IV. Not Used

V. Metals, Structural \& Miscellaneous

VI. Not Used

VII. Moisture Protection

VIII. Electrical

IX. Mechanical

3. Electrical and mechanical specifications are often sources of dispute. Though the design specifications require the installation of certain equipment, they do not unambigously specify the trade responsible for the installation. 
which it must pass, the more likely it is that the original meaning will be lost or obscured.

In addition to those drawbacks which arise from contract formation, during construction the very nature of the prime contractor-subcontractor relationship is often the source of problems. Indeed, it is not unusual that a prime contractor's interests and motivation will run contrary to those of its subcontractors. There are various examples of such contradictory interests. First, since the prime contractor is actually performing a substantial portion of the physical work on the project with its own labor force and equipment, its primary function is that of a builder. The function of administration, including the oversight of subcontractors, is secondary and consequently may not receive the necessary attention.

Even when the prime contractor does attend to the adminstration of the project, contrary interests can manifest themselves. This is particularly true in the administration of the project schedule. The prime contractor is responsible to the owner for scheduling the project work. The prime contractor's natural motivation, however, is to schedule its own work in the most advantageous manner. The efficient scheduling of subcontractor work, though important, is still a secondary consideration.

Furthermore, on a conventional project, the owner generally agrees to pay its prime contractor on a periodic (usually monthly) basis. In turn, the prime contractor typically makes payment to its subcontractors contingent upon payment by the owner. Thus, if the owner delays payment to the prime contractor, for whatever reason, the prime contractor can delay its payments to the subcontractors. ${ }^{4}$ Moreover, a prime contractor may purposely delay payment of progress payments, and especially retainage, to the subcontractors even after receiving payment from the owner. This enables the prime contractor to earn interest on the subcontractors' money or to use the funds as a bargaining chip to resolve disputes with a subcontractor. Even when the prime contractor does pay the subcontractors, he may still withhold a certain portion (usually five to ten percent) of the subcontractors' payments as retainage until the work is complete. ${ }^{5}$ This can be in addition to the retainage the owner withholds on payments to the prime contractor. Thus, a subcontractor's actual payments can be reduced by fifteen to twenty percent.

A further area of conflicting interst is the processing of changes. Obviously, the prime contractor is most interested in processing the changes to its portion of the work. A subcontractor's changes result in little financial benefit to the prime con-

4. In contrast, art. 12.4.3 of the Standard Form of Agreement Between Contractor and Subcontractor of the American Institute of Architects gives a subcontractor the right to demand payment when he bears no fault for the delay. American Institute of Architects, Standard Form of Agreement Between Contractor and Subcontractor, Doc. A401, art. 12.4.3 (Apr. 1978) [hereinafter cited as AlA Contractor-Subcontractor Agreement].

5. Many prime contractors' standard subcontracts are more restrictive in their subcontractor payment provisions than the AIA Document A401. It is not unusual that a private subcontract precludes progress payments to a subcontractor until payment is received by the prime contractor regardless of the owner's reason for delay or nonpayment. In addition, the subcontract may preclude release of a subcontractor's retainage until the owner accepts the entire project, not just the subcontractor's work. This can be especially costly to trade subcontractors whose work is completed early. 
tractor and more often are regarded as impediments to the resolution of the latter's changes. Thus, prime contractors may process their subcontractors' changes as secondary matters and have been known to negotiate away the subcontractors' changes in return for the owner's acceptance of the prime contractor's pricing.

A final perceived drawback of the conventional system is its frequent entrapment of the subcontractors in any deterioration of the owner-prime contractor relationship. As set forth above, a subcontractor's receipt of progress payments and retainage from the prime contractor often is conditioned upon the prime contractor's prior receipt of payments from the owner. It is not unusual, particularly as a troublesome project nears completion, for an owner to withhold part or all of the progress payments as leverage or protection against prime contractor claims. Consequently, the subcontractor who has continued working and incurring costs may not be paid until the owner and prime contractor resolve their differences or the subcontractor takes legal action. Should the owner-prime contractor relationship continue to deteriorate so that the owner terminates the prime contract, all subcontracts usually will be likewise terminated even though the subcontractors have performed their work on time and in accordance with the contract specifications.

Such drawbacks in the conventional contracting system of construction as described above, in conjunction with expected improvements under nontraditional construction methods, have led specialty trade contractors to welcome such techniques as construction management and design-build/fast track.

\section{III \\ Expectations of Specialty Contractors on Construction Management and Design-Build/Fast Track Projects}

An owner's primary objectives in using the nonconventional construction management and design-build/fast track systems are to save time and to reduce costs. The specialty contractor's primary objective under either the traditional or nonconventional system is to perform its contract profitably and in conformance with contract plans and specifications.

In comparison to the traditional construction project, nonconventional construction systems promise the specialty contractor a more favorable method of achieving its objective; consequently, lower contract prices can result. Thus, the owner not only lowers costs by having the work performed sooner with lower labor and material costs, but it also benefits from the contractor's bidding under more favorably perceived circumstances. This is true for both construction management and design-build/fast track techniques, whether used singly or in combination.

\section{A. Construction Management}

Construction management is a flexible term encompassing a wide variety of owner-manager-contractor relationships. ${ }^{6}$ For the specialty contractor, it usually

6. See Hart, Construction Management-CM for Short-The New Name for an Old Game, 8 For UM 210,215 
means that the owner has contracted with a professional construction management firm that will administer and manage the design and construction of the project but will not perform any actual construction duties. It also means that the owner will enter into individual prime contracts with each of the specialty contractors. ${ }^{7}$ This is in contrast to the conventional contracting system in which the specialty trade contractor has no contractual relationship with the owner.

The adminstrative and managerial duties of the construction manager (CM) typically include: acting as the owner's on-site representative, providing a liaison between the owner and the specialty contractors, administering the project schedule, and providing a quality- and cost-control system. ${ }^{8}$ The American Institute of Architects' General Conditions of the Contract for Construction, Construction Management Edition, ${ }^{9}$ which forms the basis of many owner-trade contractor contracts, specifies the CM's duties as including: acting as the owner's representative during construction and until the issuance of final payment, ${ }^{10}$ reviewing and processing all applications for payment by the contractors, ${ }^{11}$ rejecting work that does not conform to the contract (subject to the architects' review), ${ }^{12}$ and reviewing shop drawings and samples. ${ }^{13}$ Of particular significance to specialty contractors is the CM's obligation to schedule and coordinate the work: "The Construction Manager will schedule and coordinate the Work of all contractors on the Project." 14 While the specialty contractor is required to submit an estimated schedule, ${ }^{15}$ often based upon contract-specified start and completion dates, the CM must then take that trade schedule and incorporate it into the schedule for the entire project. ${ }^{16}$

For the specialty trade contractor, the CM's assumption of such duties ideally offers more profitable projects through improved project management and coordination. This expectation arises from the basic premise of the construction management system: a professional on-site manager whose sole function is to guide the project to an efficient completion. Unlike a traditional prime contractor, the CM typically contracts on a cost-plus basis with no production responsibilities. Thus, instead of being subject to a prime contractor whose primary concern is the management and profitability of its own work, the specialty contractor is subject to a $\mathrm{CM}$ whose sole task is to administer all the work for the overall benefit of the project.

(1972); Nash \& Love, Innovations in Federal Construction Contracting, 45 GEO. Wasti. L. REV. 309.365 n. 137 (1977).

7. Although less common, the CM, instead of the owner, may enter into the individual prime contracts.

8. See John E. Green Plumbing \& Heating Co. v. Turner Constr. Co., 500 F. Supp. 910, 910-11 (E.D.

Mich. 1980); Nash \& Love, supra note 6, at 365

9. American Institute of Architects, General Conditions of the Contract for Construction, Doc A201/CM (constr. management ed. June 1980) [hereinafter cited as AIA/CM General Conditions].

10. Id. art. 2.3.2.

11. Id. art. 2.3.8.

12. Id. art. 2.3.6.

13. Id. art 2.3 .17

14. Id. art. 2.3.7.

15. Id. art. 4.10 .1

16. Id. 
Further, under the construction management system, the owner-not a general prime contractor-contracts directly with each specialty trade contractor. This arrangement has two results. First, each specialty trade contractor is on an equal footing relative to the other project contractors. Second, the specialty trade contractor is subject to only one contract. Thus, progress payments and retainage cannot be unjustifiably withheld by an intermediate prime contractor. More importantly, because of its direct contract with the owner, a specialty trade contractor is not likely to be affected by an owner's deteriorating relationship with other trade contractors or even with the CM. Consequently, the owner's termination of another trade contractor, or even the CM, would not likewise terminate all speicialty contractors.

\section{B. Design-Build/Fast Track}

Design-build and fast track are related construction techniques which, like construction management, seek to shorten total project time. Under the design-build system, an owner awards an entire project to a single entity. ${ }^{17}$ That entity then designs and constructs the project. The designer and builder may be the same firm, but more often the designer subcontracts segments or trade portions of the project to various specialty contractors. By controlling the design and the award of the various construction or trade segments of the project, the designer can start the initial construction work prior to the completion or refinement of the total project design. ${ }^{18}$

The fast track technique similarly operates to start construction prior to the completion of the project design. In a fast track project, however, the owner typically hires an architect/engineer to design the project in a series of trade or bid packages. The owner or its agent (not the designer as in design-build) then solicits bids and awards the various bid packages to specialty contractors. Like designbuild, however, the fast track technique does permit the owner to award and order the start of the initial phases of trade work while the designer completes or refines the later stages of the project design.

For the specialty trade contractors, both techniques divide the total project into segments, usually based on the traditional specialties. The initial project work, such as excavation and foundations, is designed and construction is begun before the completion of the total project design. Thereafter, as the initial trade contractors make sufficient progress or complete their segments, the follow-on trade contractors commence their operations. Thus, both techniques are generally classified as forms of phased construction. A recent decision of the General Services Administration Board of Contract Appeals likened phased construction

to a procession of vehicles moving along a highway. Each vehicle represents a prime contractor whose place in the procession has been pre-determined. The progress of each vehicle, except that of the lead vehicle, is dependent on the progress of the vehicle ahead. The milestone dates have been likened to mileage markers posted along the highway. Each vehicle is required to pass the mileage markers at designated times in order to insure steady progress. $^{19}$

17. See generally Nash \& Love, supra note 6, at 350.

18. Id.

19. Pierce Assocs., 77-2 B.C.A. (CCH) \ 12,746, at 61,941 (1977). 
It is the "procession" of trade contractors commencing work prior to completion of the project design which shortens the total project time and reduces the owner's costs. In this regard, it is important to note that the design-build/fast track approach refers to the entire construction project. One portion is designed and construction is begun while the design of another portion is being finished. It does not mean that a single segment is concurrently designed and constructed. Thus, the individual trade contractor should expect that its bid package design will be accurate and adequate to construct its particular trade portion of the project.

As with construction management, design-build/fast track techniques give a specialty trade contractor the reasonable expectation of less costly, more profitable work. In this instance, however, the expectation arises from the quality of the design documents. Indeed, to the individual trade contractor, the designbuild/fast track techniques promise better design documents than the traditional system. Under the latter, the trade contractor must review the entire set of plans and specifications to identify the scope of its work. ${ }^{20}$ In contrast, dividing the total project design into specific trade packages, each with a definite and readily identifiable scope of work, enables each specialty trade contractor to identify and to bid its trade work more accurately. Further, the specialty trade contractors can anticipate that a designer's individual consideration, design, and review of each trade package will minimize design errors and omissions.

Although on first inspection it might seem that the design-build/fast track system would introduce more changes to the work than the traditional system, ${ }^{21}$ this should not typically be the case. Changes occur on virtually every major construction project. They result from unavoidable errors and omissions in preparing the plans and specifications, changes in the owner's needs, and improvements in technology. The traditional owner-prime contractor construction contract allows for such changes. Indeed, standard construction documents such as the American Institute of Architects' General Conditions of the Contract for Construction set forth the procedure for pricing changes on conventional projects."2 Similar provisions are incorporated into the American Institute of Architects standard subcontract form ${ }^{23}$ while the AIA/CM Conditions contain almost identical terms. ${ }^{24}$

On a design-build/fast track or construction management project, a trade contractor is bidding on a custom-made design package which should be as accurately and adequately designed before bid as is a conventional project design. Consequently, a trade contractor should not anticipate any more changes than it would

20. See supra notes $2-3$ and accompanying text.

21. The design-build/fast track method has the potential for increasing the number of changes or revisions during construction because early construction phases are in progress or even complete before the design of the later or last phases is complete. See Armour \& Co. v. Scott, 360 F. Supp. 319 (W.D. Pa. 1972).

22. American Institute of Architects, General Conditions of the Contract for Construction, Doc. A201, art. 12 (Aug. 1976), reprinted in Businessman's Guide to Construction 198 (1980).

23. See AIA Contractor-Subcontractor Agreement, supra note 4, art. 11.9.1

24. See AIA/CM General Conditions, supra note 9, art. 12. 
expect on a conventional project. The trade contractor should anticipate, however, faster and fairer resolution of changes because it is submitting its changes directly to the owner-not to an intermediate prime contractor (whose first consideration is to process its own change requests).

In summary, the anticipated benefits of construction management and designbuild/fast track, either singly or in combination, suggest a significant improvement over the traditional construction contracting system. The actualities of the nonconventional techniques, however, are often far short of trade contractors' expectations.

\section{IV}

\section{Actual Experience of Specialty Contractors on Construction Management and Design-Build/Fast TraCK PROJECTS}

While the construction management and design-build/fast track approaches still generate owners' expectations of lower costs and shorter performance time, the specialty contractors are finding the realities of these nontraditional construction techniques to be quite the opposite. In project after project, specialty trade contractors have experienced significant delays and cost overruns due to the failure of owners, CMs, and designers to fulfill the obligations imposed on them by the nonconventional techniques. The ultimate result has been a proliferation of expensive and lengthy litigation.

\section{A. Construction Management}

Regardless of a trade contractor's general expectations of a construction management project, its rights and obligations on any particular project are defined in large part by its contract with the owner. The typical trade contract imposes on trade contractors basically the same obligations which they would have had as traditional subcontractors. The trade contractor must perform in accordance with the contract documents, ${ }^{25}$ select and supervise its labor force, ${ }^{26}$ determine the construction means, methods, and procedures, ${ }^{27}$ obey all applicable laws, ordinances, and buildings codes, ${ }^{28}$ prepare shop drawings, ${ }^{29}$ purchase materials, and take all other steps to assure the successful completion of its work, ${ }^{30}$ all in accordance with the schedule in its contract. ${ }^{31}$

One task, however, that neither the individual specialty contractor nor all the specialty contractors together can be required to perform is to schedule and coordinate the work of the other contractors. Logically, only the CM should schedule the overall project work; indeed, it should be and is the CM's primary function.

\footnotetext{
25. Id. arts. 4.3.3, 4.5.1.

26. Id. arts. 4.4.1, 4.3.2.

27. Id. art. 4.3.1.

28. Id. art 4.7 .2 .

29. Id. art. 4.12 .4

30. Id. art 4.4.1.

31. Id. art 8.2.2.
} 
The CM alone has the total picture of the project, as well as the contractual authority to control its orderly and timely completion. In contrast, the specialty trade contractors, individually or collectively, are not in a position of project overview, nor do they have contractual control over the architect/engineer or each other.

Unfortunately, it is in the very effort and execution of scheduling and coordination that the construction management system has faltered. The failure takes three forms. First, owners and their CM's have attempted to place the contractual burden of scheduling and coordination on the trade contractors. Second, the owner-trade contract provisions have often sought to absolve the owner from liability for its own or its CM's poor scheduling. Third, many CMs, even though recognizing their contractual duties, have failed to schedule or to administer and to enforce effectively the established schedules.

1. Shifting the Duty of Scheduling and Coordination. The very purpose of the construction management technique is thwarted if the owner or the CM seeks to impose the duty of scheduling and coordination on the individual trade contractors. Nevertheless, on many projects the owners and CMs have sought to shift the duty of scheduling and coordination to the individual trade contractors. ${ }^{32}$ The result, of course, has been chaos.

Fortunately, it appears that the courts and boards of contract appeals recognize that the owner and CM must bear at least some responsibility for project scheduling and coordination, ${ }^{33}$ unless the trade contracts provide otherwise. In a recent decision, the General Services Administration Board of Contract Appeals wrote:

The Government can decide on whatever method of construction and contracting it chooses, but, in doing so, it also assumes the responsibilities inherent in its choice. With phased construction, it is obvious that the contracting officer has the obligation and duty to demand that the various contractors cooperate with the construction schedule and not interfere with the work of any other contractor. ${ }^{34}$

The duty and responsibility of scheduling and coordination remain with the owner or CM even though the specialty trade contractor's contract may require it to coordinate its work with that of other trade contractors. ${ }^{35}$ This is not to say, however, that the specialty trade contractor has no responsibility. Each trade contractor must schedule its material deliveries and coordinate its own forces in conjunction with the progress of its work. ${ }^{36}$ Moreover, the specialty trade contractor

32. See, e.g. , Jacobson \& Co., 80-2 B.C.A. (CCH) \14,521 (1980); Pierce Assocs., 77-2 B.C.A. (CCH) 』 $12,746(1977)$.

33. See Gateway Erectors Div. v. Lutheran Gen. Hosp., 102 Ill. App. 3d 300, 302, 430 N.E.2d 20. 21 (1981); see also L.L. Hall Constr. Co. v. United States, 379 F.2d 559 (Ct. Cl. 1966); Hoffman v. United States, 340 F.2d 645 (Ct. Cl. 1964); Peter Kiewit Sons' Co. v. United States, 151 F. Supp. 726 (Ct. Cl. 1957); Jacobson \& Co., 80-2 B.C.A. (CCH) 9 14,521, at 71,565 (1980); Pierce Assocs., 77-2 B.C.A. (CCH) ๆ $12,746(1977)$

34. Jacobson \& Co., 80-2 B.C.A. (CCH) \14,521, at 71,565 (1980).

35. See, e.g., Paccon, Inc. v. United States, 399 F.2d 162 (Ct. Cl. 1968); John A. Johnson \& Sons v. United States, 180 F.2d 969 (Ct. Cl. 1967); Hoffman v. United States, 340 F.2d 645 (Ct. Cl. 1964); Jacobson \& Co., 80-2 B.C.A. (CCH) I 14,521 (1980); Pierce Assocs.. 77-2 B.C.A. (CCH) I 12.746 (1977).

36. Gaede \& Bynum. The Multi-Prime Job, 79-3 Construction Brierincis, May 1979, at 7. 
must inform the owner or the CM of its progress and future sequence of operations. ${ }^{37}$ Once informed, however, the owner and CM have the legal and logical responsibility to utilize that knowledge and authority to schedule and coordinate all trade contractors' work from project start to completion. ${ }^{38}$

2. Absolution from Damages for Delay. While contractually obligated to schedule and to coordinate the project work, many owners and CMs have sought to absolve themselves from all responsibility for the fulfillment of those duties. This is most often attempted by the inclusion of a "no damages for delay" clause in the trade contracts. Alternatively, some trade contracts have directed trade contractors to look to one another for recovery of delay damages.

"No damages for delay" clauses are a common fixture of traditional project prime contracts and subcontracts. ${ }^{39}$ Generally, contractors, including prime contractors and subcontractors on traditional projects and trade contractors on construction management projects, each have a contractual right to recover damages for delays which result from the acts or omissions of the parties administering their contracts. ${ }^{40}$ Owners and their CMs, however, utilize a "no damages for delay" clause in an attempt to preclude contractually the trade contractors' right to recover such damages. Typically, the clauses are structured to limit trade contractors' remedies for any delays to noncompensable time extensions regardless of cause, duration, or cost of the delays. ${ }^{41}$

While courts do recognize the validity of "no damages for delay" clauses, they will not enforce the clauses without exception or limitation. ${ }^{42}$ In fact, traditional construction project contractors bearing the responsibility for scheduling and coordination may overcome such clauses and recover delay damages when: (i) the delay was neither intended nor contemplated by the contracting parties to be within the terms of the particular clause; (ii) the delay resulted from fraud, misrepresentation, or other bad faith by the party seeking the protection of the clause; (iii) the delay was of such unreasonable length as would amount to an abandonment of the contract; or (iv) the delay resulted from the other party's active interference with or hinderance of contract performance. ${ }^{43}$

37. Id.

38. Id. ; see AIA/CM General Conditions, supra note 9, art. 2.3.7.

39. Annot., 74 A.L.R.3d 187, $194-96$ (1976); see also Comment, No Damages Clauses in Construction Contracts: A Critique, 53 WASH. L. REV. 471 (1978) (government contracts).

40. See L.L. Hall Constr. Co. v. United States, 379 F.2d 559 (Ct. Cl. 1966).

41. For example, "no damages for delay" clauses are commonly worded as follows:

In the event the Subcontractor is delayed in the commencement, prosecution or completion of its work by any act, omission, neglect or default of the Owner, Prime Contractor or of anyone employed by them, or of any other subcontractor or third party on the Project, or by any damage caused by fire or other casualty or by any extraordinary conditions arising out of war or governmental actions, or by any other cause all beyond the control and without the fault or neglect of Subcontractor, then Subcontractor shall be entitled to a noncompensable time extension only.

While the wording typically varies, in each case one party is seeking to preclude claims for impact and delay costs for which it might otherwise have contractual liability.

42. See, e.g., United States Steel Corp. v. Missouri Pacific R.R., 668 F.2d 435 (8th Cir. 1982); Blake Constr. Co. v. C.J. Coakley Co., 431 A.2d 569 (D.C. 1981); City of Seattle v. Dyad Constr., 17 Wash. App. 501,565 P.2d 423 (1977).

43. See United States Steel Corp. v. Missouri Pacific R.R., 668 F.2d 435, 438 (8th Cir. 1982); Blake 
Although the exceptions to "no damages for delay" clauses have arisen almost exclusively in cases involving traditional construction contracts, these exceptions are logically applicable in the construction management context as well. In applying the exceptions listed above, courts have based their decisions on a factual investigation of what the parties contemplated, and the cause and length of the delay. ${ }^{44}$ In the construction management context, such an investigation would reveal that the construction management technique was developed to shorten construction time and that the CM is the party with ultimate scheduling authority. It would also expose the relative impotence of the trade contractors to control the overall project schedule. Such findings would lead to a more lenient threshold for invoking the exceptions to enforcing "no damages for delay" clauses on construction management projects.

Moreover, given the authority of the CM, it seems logical that any act or failure on the CM's part which delays a trade contractor could be regarded as "active interference," an exception to the "no damages for delay" clause. ${ }^{45}$ Also, given that the purpose of the construction management system is to shorten construction time by more efficient management, any delay should be regarded "as beyond the comtemplation of the parties," or "of an unreasonable duration" per se, either of which constitutes an exception to the "no damages for delay" clause. ${ }^{46}$

The only case reported to date in the construction management context is John E. Green Plumbing $\mathcal{G}^{\circ}$ Heating Co. v. Turner Construction Co. ${ }^{47}$ In that case, a trade contractor sued the CM for intentional interference with his contract. The CM moved for summary judgment on the grounds that the "no damages for delay" clause in the specialty contract barred the contractor's action. The court, applying Michigan law, listed the standard exceptions to the "no damages for delay" clause and determined that proof of the allegations in the complaint could establish that the CM had intentionally interfered with the contractor's performance. ${ }^{48}$ Thus, summary judgment was denied. Unfortunately, the court did not discuss the factual allegations which led to its conclusion that active interference could be established.

As an alternative to the "no damages for delay" clause, some owners and their CM's have relied upon contract clauses which require a delayed trade contractor

Constr. Co. v. C.J. Coakley Co., 431 A.2d 569, 578-79 (D.C. 1981). See generally Annot., 74 A.L.R.3d 187 (1976).

44. See cases cited supra note 43. If an injured party cannot fit the facts of his delay damages claim into one of the recognized exceptions, the courts and boards will not hesitate to recognize the barring effect of a "no damages for delay" clause. See, e.g., City of Houston v. R.F. Ball Constr. Co., 570 S.W.2d 75 (Tex. Civ. App. 1978); Western Eng'rs, Inc. v. State Board Comm'n, 20 Utah 2d 294, 437 P.2d 216 (1968).

45. Article 4.10.1 of the AIA/CM General Conditions, supra note 9, specifies that the CM shall coordinate the contractor's progress schedule with the schedule for the entire project. Article 2.3.7 of the AIA/CM General Conditions, supra note 9, further specifies that the CM is responsible for scheduling and coordinating the work of all contractors on the project. Should the CM fail to meet these responsibilities, thereby disrupting the trade contractors' work, it is more than a simple mistake, error in judgment, lack of total effort or lack of complete diligence; it is active interference.

46. For an example of a delay of "unreasonable duration" under a traditional contract, sec E.C. Nolan Co. v. State, 58 Mich. App. 294, 227 N.W.2d 323 (1975).

47. 500 F. Supp. 910 (E.D. Mich. 1980).

48. Id. at 913 . 
to recover damages from the contractor who was responsible for the delay. In one of the first construction management cases litigated under such facts, Pierce Associates, ${ }^{49}$ the U.S. Government attempted to absolve itself and its CM from responsibility for any delays by citing to the following clause included in all the trade contracts, which in effect directed a damaged contractor to seek recovery from the other project trade contractors:

Should the contractor sustain any damage through any act or omission of any other con. tractor having a contract with the Government for the performance of work upon the site or of work which may be necessary to be performed for the proper prosecution of the work to be performed hereunder, or through any act or omission of a subcontractor of such contractor, the contractor shall have no claim against the Government or the Government's consultants for such damage, but shall have a right to recover such damage from the other contractor under the provision similar to the following provisions which has been or will be inserted in the contracts with such other contractors. 50

The General Services Adminstration Board of Contract Appeals held that the contractor could recover delay dàmages from the Government regardless of the exculpatory contract language, basing its decision on the fact that the Government contracting officer had an affirmative duty to schedule the work. ${ }^{51}$

The New Jersey courts have absolved the owner and its scheduling consultant from any liability for failure to coordinate when one of the multiple contractors, the general construction contractor, had specifically agreed in its contract to coordinate and schedule all construction work. In two cases arising out of the same project, Edwin J. Dobson, Jr., Inc. v. Rutgers ${ }^{52}$ and Broadway Maintenance Corp. v. Rutgers, ${ }^{53}$ the courts looked to the plain language of the contract awarded the general construction contractor, Frank J. Briscoe Co., Inc., and ruled that Briscoe had expressly agreed to coordinate the work of all contractors on the project. The courts further noted that each of the multiple trade contracts, including Briscoe's, provided that the specialty trade contractors would rely on the general construction contractor to supervise, direct, control, and manage the project to completion. Under such circumstances, the courts held that the specialty trade contractors could not bring an action against the owner for a failure to coordinate.

Such rulings show little inconsistency with the ruling in Pierce Associates. In Pierce Associates, the government attempted to contract away liability, yet its contract was silent on the issue of coordination responsibility. In Dobson and Broadway Maintenance, the owner not only contracted away liability, but also the responsibility of coordination. From these decisions, it seems clear that the party bearing the duty of coordination, either expressly or impliedly, will be liable for damages resulting from a breach of that duty.

3. Construction Manager's Failure to Maintain and Enforce the Project Schedule. The third major difficulty with construction management contracts has been the CM's failure to maintain and enforce the project schedule in the field. Scheduling is a




three-step process: 1) preparing a schedule; 2) updating the original schedule to recognize jobsite reality; and 3) assuring compliance with the current schedule. The first and second steps are nothirig more than the drafting and calculating of a reasonable schedule in accordance with the owner's needs and then updating the schedule to reflect accurately the jobsite conditions and progress.

The third step is the most difficult: enforcement of the current updated project schedule to assure that each contractor starts and completes his work on time as well as in conjunction with the progress of the other trade contractors. In Pierce Associates, ${ }^{54}$ the board of contract appeals described this duty as follows:

The normal bidder, told that the Government will set the priorities for another contractor in terms of the bidder's own performance, and scaled to his work ('so that the turnover of houses will be accomplished at the same time as the turnover of applicable related utilities') would naturally think that the Government would follow through on the priority schedule, so far as it reasonably could. The normal bidder, anxious for reassurance, would hardly be satisfied with a paper schedule, not to be enforced or policed in any way by the defendant. He would certainly assume that this is not all the Government promised, and he would be entitled to make that assumption. ${ }^{55}$

Although the Government argued in Pierce Associates that it could not be held responsible for the delays of preceding contractors, the board of contract appeals squarely placed such responsibility on the Government and its construction manager. In denying the Government's motion for reconsideration, the board wrote:

The Government also points out that the Board's decision will either subject it to multiple litigation by requiring it to first defend itself against the aggrieved contractor and then sue to collect damages from the inefficient contractor or contractors, or force it to abandon use of the phased construction contract altogether. The choice of which type of contract to utilize for a particular project is, of course, the Government's. Since every form of contracting has some disadvantages and requires the Government to assume some responsibility, it is up to the Government to consider the alternatives and decide which type of contract would work most successfully for any given project. The Board neither forces the use or abandonment of any particular form of contracting nor creates unnecessary litigation, but merely decides appeals in accordance with the contract that the parties have agreed upon. ${ }^{56}$

The duty of the owner and the CM to schedule and coordinate is clear. It is when the CM attempts to contract away that duty, or to limit its liability when it breaches that duty, or actually breaches that duty, that the trade contractors are most often disappointed in their reasonable expectations of the construction management system.

\section{B. Design-Build/Fast Track}

As set forth above, a design-build/fast track project should give the bidding trade contractor the reasonable expectation of having a better and more complete set of plans for his portion of the work than under a traditional subcontract. ${ }^{57}$ In too many instances trade contractors have found plans to be far less satisfactory than anticipated. First, the plans and specifications contain more, not fewer,

54. 77-2 B.C.A. (CCH) थ 12,746 (1977)

55. Id. at 61,942-43 (quoting from Paccon, Inc. v. United States, 399 F.2d 162, 169-70 (Ct. Cl. 1968)).

56. Id. at 63,862 (1978).

57. See supra p. 45. 
defects than traditional project designs. Second, the individual bid packages often do not together constitute a whole project. Both problems seem to have their bases in one cause-premature release of the individual bid packages to the specialty contractors.

It is, of course, the purpose of design-build/fast track techniques to shorten the total duration of the construction process. Thus, the sooner the first bid packages are released, the sooner construction can commence. If the early bid packages are released before the package designs are complete, however, the project may commence at an earlier date, but it is almost certainly doomed to be completed at a much later date than anticipated, and usually at a much greater cost.

When the owner or its agent issues the initial trade packages (caissons, excavation, foundations) before the package designs are complete, the contractor will experience many more changes than would normally be expected. This is true because the changes will be developmental changes as well as corrections of errors and omissions. Developmental changes are those which are found to be necessary as the design of the project continues. Corrections of errors and omissions are changes to correct engineering or design mistakes. These problems occur even on traditional projects, but they are multiplied when bid package plans and specifications are released before the package design has been completed and thoroughly checked for accuracy.

An often more serious problem occurs when the various bid packages together do not constitute the entire project or are based on different dimensions or criteria. An example of this occurs when a trade contractor is required to build on prior work, portions of which are simply omitted or forgotten in the design of the bid packages and now do not exist in the field. A more common example has been the discovery of many trade contractors that standard construction tolerances, even when referenced in the bid package plans and specifications, have not actually been taken into account by the trade package designers. Consequently, trade contractors can perform their trade work as specified yet find that work supposedly compatible by design is incompatible in the field. Similarly, separate trade package designs prepared by different individuals within the designer's office may depict a common area, yet the dimensions or elevations conflict.

The result of these shortcomings, especially when discovered after work has commenced, is delay of the project and severe increases in the contractors' performance cost. Each change to overcome a particular shortcoming has to be processed through the construction manager to the architect/engineer and returned to the contractor. When the discovery and processing occurs prior to construction, the impact on contractors is lessened but not eliminated. When it occurs during actual construction, so that labor forces have to cease work and wait for new instructions, it can easily double or triple the cost of performance. ${ }^{58}$

To compound the problem, owners, their CMs, and designers tend to rely solely on the procedures for changes which are set forth in the trade contracts.

58. Often the very inflation savings which are sought by initiating construction during design are lost while awaiting clarifications and revisions. 
These procedures entitle the trade contractors to compensation for the changes. Indeed, most trade contracts contain very detailed provisions for calculating and processing change orders. ${ }^{59}$ The dilemma of many design-build/fast track projects has been that the changes are so numerous in comparison to the original project trade work that the trade contract's calculation provisions in no way account for the incurred impact and loss-of-efficiency costs.

In order to circumvent many owners' refusals to recognize impact costs, trade contractors have sought recovery under a theory of "cardinal change."60 A cardinal change occurs when the number and/or nature of changes is so great that the project is deemed to be totally different from the project at the time of bid. ${ }^{61}$ In at least one fast track case, the court allowed the contractor to recover its inefficiency costs due to the sheer volume of changes even though the court did not address whether the quantity and type of changes constitutes a "cardinal change."62

\section{Combined Effect of Construction Management and Design-Build/Fast Track}

When the construction management and design-build/fast track methods are utilized together on a single project, the shortcomings of each technique are compounded. It is not uncommon on such projects for an owner or a CM which is under pressure to commence work to issue bid packages for construction prematurely. The bid package designs may be incomplete or the trade contractors may be notified to proceed before the project can accommodate them. Such events can only lead to delays which in turn delay follow-on contractors. The trade contractors then find themselves confronted with "no damages for delay" clauses or other exculpatory language. Although, as set forth above, courts and boards of contract appeals have allowed remedies for these problems, such remedies are no substitute for the frustrated expectations of both the owner and the specialty contractor. The owner has not achieved its savings of time and costs, and the contractor has been made whole, if at all, only after extensive and expensive litigation.

\section{$\mathrm{V}$}

\section{CONCLUSION}

To date, nonconventional construction methods have not met the expectations of trade contractors. The problem does not, however, seem to be in the techniques. The techniques are valid and can work. The failures result from the owners', CMs', and designers' refusals to accept or fulfill their respective responsibilities under a system created and implemented for their benefit.

It is a fact that owners select construction management and design-build/fast

59. See supra notes 22-24.

60. See, e.g., Edward R. Marden Corp. v. United States, 442 F.2d 364 (Ct. Cl. 1971).

61. Id. at 369 .

62. See E.C. Ernst, Inc. v. Koppers Co., 476 F. Supp. 729 (W.D. Pa. 1979), modified, 626 F.2d 324 (3d Cir. 1980). 
track procedures to save time and reap financial benefits. The expectation that the owners create and intend to create is that of a fairer, more efficient system for the trade contractors than the traditional contracting procedure. Indeed, if the owners did not create such an expectation, the result would be higher bids and no cost savings for the owners.

If owners are willing to accept the benefits of the nonconventional construction techniques, they must also be willing to accept the consequences of their own acts and omissions. None of the nonconventional construction techniques is a panacea for an owner's or its team's rejection or breach of their duties. If, in an effort to save time, the owner or its team releases bid packages before the individual packages are complete, and subsequent changes occur, the owner must pay. Likewise, the owner must not attempt to avoid its responsibilities for delays which it has agreed to prevent. If the owner and his team perform their responsibilities, the owner and the trade contractors will achieve their expectations. If, however, the owner or its team does not meet its responsibilities, the owner must compensate the contractor. It is as much a part of the bargain for the owner as are the anticipated cost savings. 